\title{
How does pipeline construction affect land desertification? A case study in northwest China
}

\author{
Peng Shi ${ }^{1,2} \cdot$ Yong Huang ${ }^{3}$ - Chen Chen $^{3}$ - Yafeng Wang ${ }^{1}$. \\ Jun Xiao ${ }^{1,2} \cdot$ Liding Chen ${ }^{1}$
}

Received: 12 January 2015/Accepted: 5 March 2015/Published online: 14 March 2015

(C) Springer Science+Business Media Dordrecht 2015

\begin{abstract}
The expansion of large pipelines can strongly affect fragile ecosystems in arid regions. However, the issue of oasis desertification due to pipeline construction has rarely been addressed. In this study, three parallel pipelines routed through the Zhangye Oasis located in the middle Heihe River Basin in northwest China were chosen as a case study, and the intensity and extent of the pipeline construction disturbances on oasis desertification were evaluated using satellite images. The results indicated that land desertification increased from 20,427 ha before the pipeline disturbance to 26,312 ha after the construction in the 5000-m buffer zone. The relative rate of land desertification was used to identify the cumulative impact of pipeline disturbance. The threshold distance of the first pipeline's disturbance was 2000-3000 m. However, after the second and third pipeline installations, the threshold extended to $3000-4000 \mathrm{~m}$, which may result from the cumulative impact of the incremental projects. The disappearance of soil and vegetation, and rivers across was the direct impacts of the pipelines' construction on oasis desertification. Cutting and grazing along the ancillary road made for increasing reclamation led to indirect impacts of the pipelines' construction on oasis degradation. To reduce the effects of pipeline disturbance on oasis desertification, the implementation of mitigation measures such as backfilling the removed soil, recovery of the local vegetation, retirement of the degraded cropland, limitation of ancillary roads, and cross-river cofferdam diversions are recommended for the environmental management of pipeline projects.
\end{abstract}

Keywords Cumulative effect · Heihe River Basin - Land desertification · Oasis · Satellite observation · Pipeline

Liding Chen

liding@rcees.ac.cn

1 State Key Laboratory of Urban and Regional Ecology, Research Center for Eco-Environmental Sciences, Chinese Academy of Sciences, Beijing 100085, China

2 University of Chinese Academy of Sciences, Beijing 100049, China

3 Centre for Environmental Engineering Evaluation, Ministry of Environmental Protection of PRC, Beijing 100012, China 


\section{Introduction}

Oases are special landscapes interspersed in the wide deserts of the Gobi and have received great attention for their social and ecological values (Xie et al. 2014; Yang 2001). Oases represent only a very small portion $(4 \%)$ of the land surface, yet they are important for human well-being, accommodating about $95 \%$ of the population and creating more than $90 \%$ of the social wealth in arid regions (Yang et al. 2007). Maintaining oasis ecosystem stability has become an important issue for regional ecosystem management and sustainability. Land desertification is a serious global environmental problem, and oasis desertification poses a threat to the sustainable development of oases (D'Odorico et al. 2013; Liu et al. 2010). Many studies have focused on the impacts of climate change and human activities on oasis desertification (Qi and Luo 2006; Xu et al. 2010). However, the expansion of large-scale infrastructure, which increases oasis degradation, has received little attention.

The worldwide expansion of linear projects such as roads, gas and oil pipelines, railways, and power lines is the most ubiquitous features of construction projects. The key projects of the westto-east pipelines in China, which began construction in 2002, pass through the Hexi Corridor in northwest China and are characterized as the main physiognomies of the Gobi desert. These linear projects are known to have significant environmental impacts on fragile ecosystems in arid regions (Coiffait-Gombault et al. 2012). The construction of these pipelines involved a variety of disturbances that influenced soil, vegetation, and landscapes. During the pipeline installation, the ground excavation directly degraded soil quality and changed the physical and chemical soil properties (Shi et al. 2014). The linear clearance of vegetation and topsoil for pipeline installation reduced land stability and increased soil erosion (Yu et al. 2010). In arid areas, vegetation destruction and the disturbance of fixed sand dunes by pipeline construction aggravated land desertification (Chen and Gao 2006). Thus, pipeline disturbances to oases-desert ecosystems are extensive. However, the impacts of oasis desertification have been rarely addressed in recent years.

There are three parallel west-to-east pipelines crossing the Hexi Corridor. The primary issue of multiple project construction is the cumulative impact, which may result from individually minor, but collectively significant, actions that occur over a period of time (Council on Environmental Quality 1997). The parallel pipelines routed through the oasis may cumulatively contribute to significant environmental changes, and the analysis of these impacts is particularly relevant for oasis degradation. The determination of the cumulative impacts of pipeline construction will improve the accuracy and quality of state-required environmental impact assessments (EIA).

In the present study, we assessed the impacts of the three pipelines on oasis desertification using Landsat images. The aims of this study were to (1) identify the intensity and extent of pipeline construction disturbances on oasis desertification and (2) analyze the cumulative impacts of multi-pipeline construction. We hypothesized that the cumulative projects would potentially expand the spatial scale and time duration of the disturbances. The results will help environmental managers to comprehend the desertification mechanisms caused by pipeline construction and provide a basis for land desertification control.

\section{Methods}

\subsection{Pipeline introduction}

The 4000-km west-to-east gas pipeline I, with a $1016 \mathrm{~mm}$ diameter, is the first large pipeline project in China and traverses nine provinces from Xinjiang to Shanghai. It was constructed in 2002 and put into service in 2004. Another natural gas pipeline, the $4843 \mathrm{~km}$ west-to-east gas 
pipeline II, is the longest pipeline in China and was constructed between 2008 and 2010. The 2000-km west crude oil pipeline was built between 2005 and 2006, beginning in Urumqi in the Xinjiang Uygur Autonomous Region and ending in Lanzhou in Gansu province. The China National Petroleum Corporation (CNPC) built all three pipelines and selected the pipeline routes before their construction. The three pipelines run parallel in most areas in Xinjiang and Gansu and are located less than $100 \mathrm{~m}$ apart from each other. During the construction period, a 30- to 40-m-wide pipeline right-of-way (RoW) was cleared for operation and divided into three zones: trench, piling, and working areas. The trench in the middle of the RoW comprises a 2-mwide channel in which the pipeline is buried. The 15-m-wide working area is used for vehicular traffic and operations at one side of the trench. The piling area is cleared to stockpile soil excavated from the trench (about $15 \mathrm{~m}$ from the other side of the trench). After the pipeline began service, a 5-m-wide road was built for pipeline maintenance.

\subsection{Study area}

The three parallel pipelines pass through the Zhangye Oasis-desert in the middle reaches of the Heihe River, which was chosen as the case study area and is located between $99^{\circ} 52^{\prime}-100^{\circ} 47^{\prime} \mathrm{E}$ and $38^{\circ} 48^{\prime}-39^{\circ} 18^{\prime} \mathrm{N}$ (Fig. 1). The climate in this region is characterized as arid with a mean rainfall of $130 \mathrm{~mm}$, which mostly occurs in the summer from June to late September. The mean annual air temperature in this area ranges from 8 to $10{ }^{\circ} \mathrm{C}$, and the mean monthly lowest and highest temperatures are observed in January and July, respectively. The natural vegetation in the area is temperate dwarf shrub and sub-shrub desert vegetation dominated by Chenopodiaceae, Zygophyllaceae, Ephedranceae, Asteraceae, Poaceae, and Leguminosae (Zhao et al. 2005). The main crop planted is corn (Zea mays).

\subsection{Image processing and classification}

Landsat remote sensing images with a ground resolution of $30 \mathrm{~m}$ are globally used for land-use change detection and pertinent EIAs. In this study, four sets of Landsat 5 TM images (July. 20, 2001; Sep. 14, 2004; Aug. 3, 2006 and Aug. 14, 2010) downloaded from the United States Geological Survey (USGS; http://glovis.usgs.gov) were selected to quantitatively measure the impacts of pipeline disturbances on land desertification. Geometric correction, atmospheric correction, and other image processing techniques were conducted with ENVI 5.0 ${ }^{\circledR}$ software. These time series Landsat images were georeferenced using 38 ground control points, and the root-mean-square error was found to be $<0.5$ pixels. The nearest-neighbor method was used to resample the images to produce $30 \mathrm{~m} \times 30 \mathrm{~m}$ pixels for the TM images (Yan et al. 2007). The supervised classification method was used to map the 2001-2010 land-cover types. We classified the land-use types of the study area into eight categories: cropland, forestland, grassland, urban/developed land, water, beach land, Gobi desert (mainly covered by gravels), and sandy desert (mainly covered by sand). The Gobi and sandy desert land-cover types were considered as desertified land according to Chinese desertification classification studies (Wang et al. 2013). A field check was conducted in August 2011 to validate the accuracy of the land-use map (Fig. 1), and the validation results showed that the mapping accuracy approached $95 \%$.

\subsection{Buffering}

Buffer analysis for identifying areas surrounding geographic features has been widely used to analyze ecosystem pattern changes due to project construction (Liu et al. 2008; Zhao 


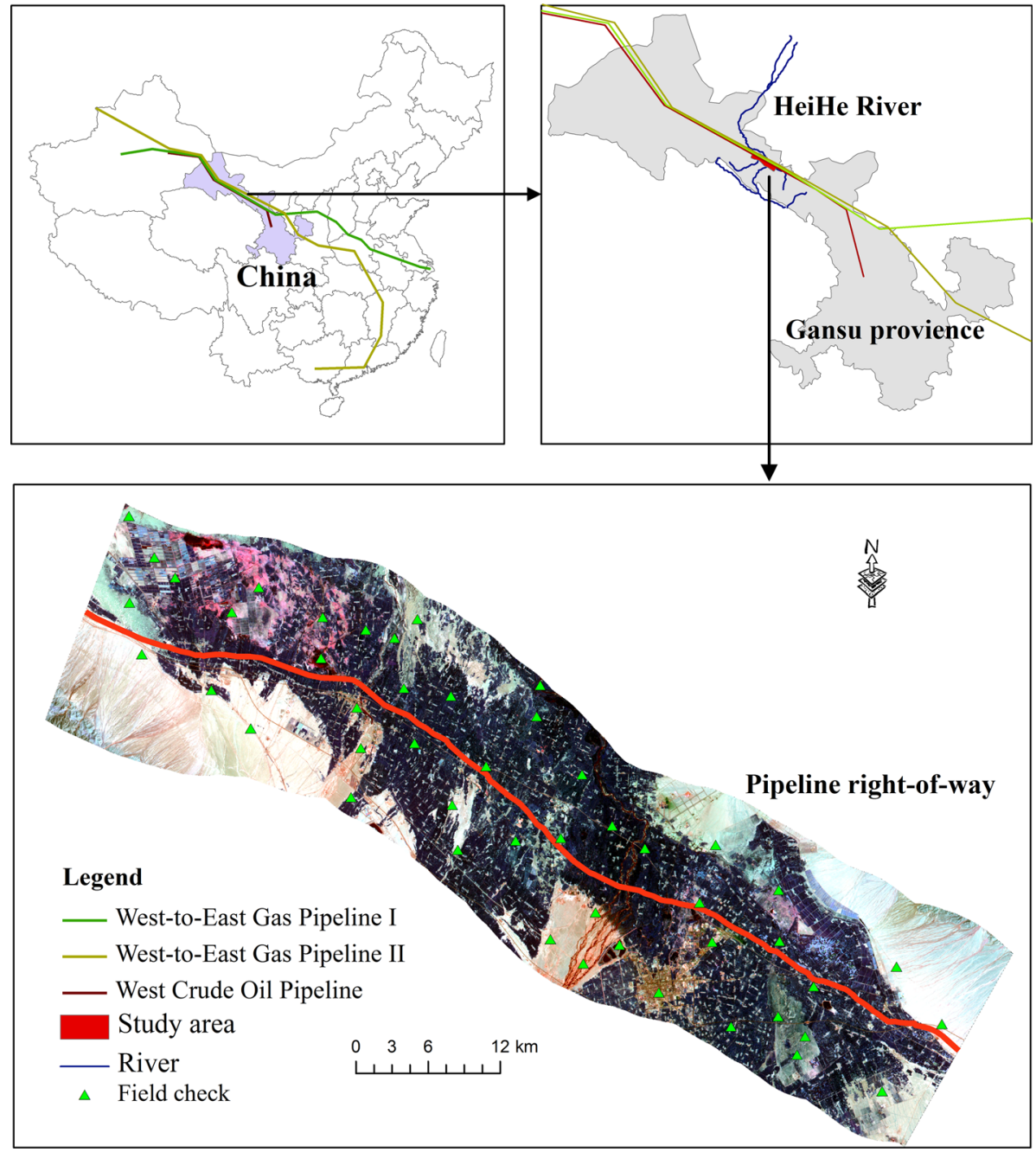

Fig. 1 Three parallel pipelines trenched through the Zhangye Oasis in the middle of the Heihe River Basin in northwest China. The west-to-east gas pipeline I was built in 2004, the west crude oil pipeline in 2006, and the west-to-east gas pipeline II in 2010

et al. 2013). Buffer zones along the pipeline were created at $500 \mathrm{~m}$ intervals within $1000 \mathrm{~m}$ from the pipeline and at $1000 \mathrm{~m}$ intervals between 1000 and $5000 \mathrm{~m}$ from the pipeline. The area between $9000-10,000 \mathrm{~m}$ from the pipeline was set as a control. All the geographic information system layers were then clipped to these buffers.

\subsection{The relative rate of land desertification}

To assess the cumulative impact of the projects, we assumed that the rates of land desertification in the oasis before construction were similar. The natural land desertification rate $(\mathrm{t})$ was calculated in the $9000-10,000 \mathrm{~m}$ buffer. 


$$
(1+t)^{n} \times A=A_{n}
$$

$A$ is the land desertification area in the control buffer, and $A_{n}$ is the land desertification area after $n$ years (the pipeline construction period) in the control buffer.

The relative rate of land desertification $(r)$ in the buffers from 500 to $5000 \mathrm{~m}$ was used to identify pipeline disturbance, and the natural land desertification was considered.

$$
r=\frac{L_{n}-(1+t)^{n} \times L}{L}
$$

$L$ is the land desertification area in the disturbance buffer, and $L_{n}$ is the land desertification area after $n$ years (pipeline construction period) in the disturbance buffer.

\section{Results}

\subsection{Land-use change of the oasis after pipeline construction}

The land-use maps before construction began (2001) and after the three pipelines were constructed (2004, 2006, and 2010) are displayed in Fig. 2. The Zhangye Oasis intersperses in the desert environment. Cropland and Gobi dominated the oasis and occupied 45.9 and $36.2 \%$ of the area, respectively. Urban/developed land and grassland were also the important land-use types in this region, occupying 6.1 and $5.0 \%$ of the area, respectively. The percentages of desertified land (sandy desert and Gobi) in the different buffer zones $(0-5000 \mathrm{~m})$ before pipeline disturbance (2001) ranged from 15.2 to $34.2 \%$ (Table 1). The percentages of urban/developed land were similar in the six buffers in 2001 and were all lower than $10 \%$. There was an increasing tendency of Gobi during the years from 2001 to 2010, and cropland showed a significant decrease after the three pipeline construction (Fig. 2). The desert lands in all the buffers expanded rapidly after the pipeline construction, from 20,427 ha (in 2001, before pipeline disturbance) to 21,812 ha (in 2004, after the first pipeline's construction), 24,076 ha (in 2006, after the second pipeline's construction), and 26,312 ha (in 2010, after the third pipeline's construction). Figure 3 presents the spatial distribution of six types of land desertification during the periods of three pipeline disturbance. The significant increase in land desertification mostly occurred in the areas near the pipeline (in the 0- to 3000 -m buffer zones). Three land types most prominently experienced desertification after the pipeline disturbance: cropland, forestland, and grassland. In particular, the land-use change in cropland contributed about $30 \%$ to the desert land increase, totaling 1119, 1174, and 1586 ha after the first, second, and third pipeline constructions, respectively (Table 2). Grassland was another main source for land desertification increase and 978, 757, and 434 ha of grassland changed to Gobi and desert after the first, second, and third pipeline constructions, respectively. There was a total of 2966 ha of forestland changed to desert land after three pipelines disturbance.

\subsection{Cumulative impacts of pipeline construction on oasis desertification}

To study the cumulative impacts of multi-pipeline disturbances on oasis desertification in detail, adjacent buffer zones were created around the pipelines. After the first pipeline was completed, the relative rate of increase in land desertification was highest near the pipeline (0- to 500-m buffer zone), indicating strong direct effects of pipeline construction on the nearby oasis desertification (Fig. 4). Soil and vegetation clearance in the pipeline RoW was 

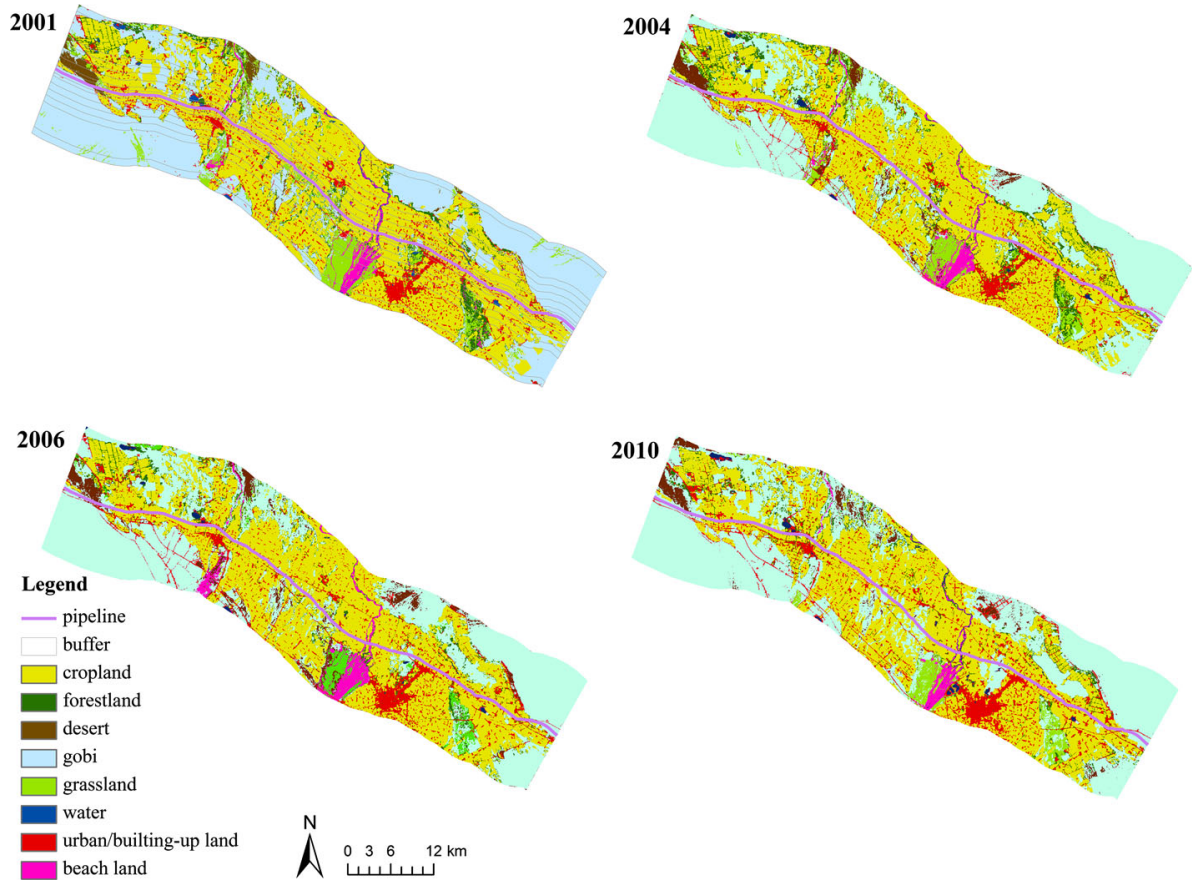

Fig. 2 Land-use maps of the Zhangye Oasis in 2001 (before pipeline construction), 2004 (after the first pipeline), 2006 (after the second pipeline), and 2010 (after the third pipeline)

Table 1 Land-use types in different buffer zones in 2001 (ha)

\begin{tabular}{lllrlllll}
\hline Buffer zone $(\mathrm{m})$ & Cropland & Forestland & Desert & Gobi & Grassland & Water & $\begin{array}{l}\text { Urban/ } \\
\text { developed land }\end{array}$ & $\begin{array}{l}\text { Beach } \\
\text { land }\end{array}$ \\
\hline $0-500$ & 5344 & 219 & 162 & 1053 & 415 & 33 & 676 & 50 \\
$500-1000$ & 5322 & 290 & 201 & 1003 & 252 & 48 & 774 & 57 \\
$1000-2000$ & 9878 & 705 & 545 & 2529 & 350 & 173 & 1562 & 138 \\
$2000-3000$ & 8680 & 789 & 339 & 3994 & 588 & 42 & 1121 & 315 \\
$3000-4000$ & 7907 & 742 & 84 & 5089 & 699 & 35 & 962 & 344 \\
$4000-5000$ & 7508 & 954 & 110 & 5309 & 736 & 54 & 882 & 297 \\
$9000-10,000$ & 5011 & 809 & 326 & 7775 & 971 & 181 & 477 & 213 \\
\hline
\end{tabular}

the main reason for the land desertification in this buffer zone. The arid ecosystems are characterized by low resilience after pipeline disturbance, and soil excavation affects plant community (Coiffait-Gombault et al. 2012). The rate then decreased with increasing distance from the pipeline. The relative rates between the adjacent buffer zones stabilized at a low level, suggesting a threshold distance of pipeline disturbance. The rate varied minimally from 2000-3000 m to far away buffer zones after the first pipeline construction, and $2000-3000 \mathrm{~m}$ was considered as the threshold distance. However, the disturbance distance extended to the 3000- to 4000-m buffer zone after the second and third pipeline construction. The extended threshold distance from $2000-3000 \mathrm{~m}$ to $3000-4000 \mathrm{~m}$ as a 

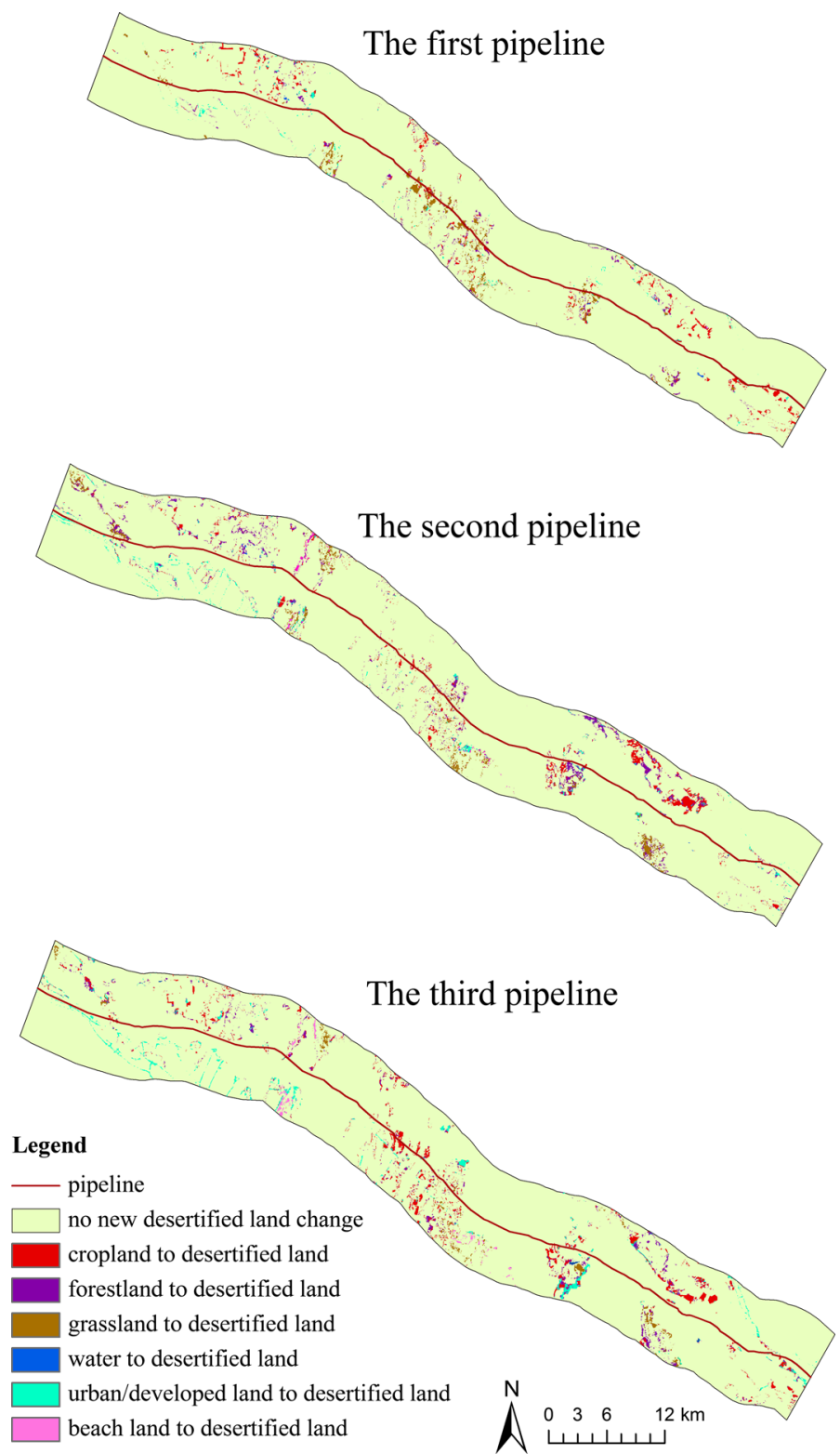

Fig. 3 Desertification land change matrix maps of the 5000-m buffer zone of the three west-to-east pipelines

result of the multi-pipeline constructions was considered as the cumulative spatial impact. The results indicated that the subsequent pipeline constructions expanded the spatial scale of the effects of pipeline disturbance on oasis desertification, confirming our initial hypothesis. The pipeline construction involving various human activities resulted in land desertification. The multiple projects increased the driving forces of oasis destruction and extended the disturbance distance. 
Table 2 Desertification land changes matrix in the 5000-m buffer zones after three pipelines disturbance (ha)

\begin{tabular}{|c|c|c|c|c|c|c|c|c|c|}
\hline \multirow[t]{2}{*}{ Land-use types } & \multicolumn{3}{|c|}{ The first pipeline } & \multicolumn{3}{|c|}{ The second pipeline } & \multicolumn{3}{|c|}{ The third pipeline } \\
\hline & Desert & Gobi & $\begin{array}{l}\text { Deserted } \\
\text { land }\end{array}$ & Desert & Gobi & $\begin{array}{l}\text { Deserted } \\
\text { land }\end{array}$ & Desert & Gobi & $\begin{array}{l}\text { Deserted } \\
\text { land }\end{array}$ \\
\hline Cropland & 11 & 1108 & 1119 & 14 & 1160 & 1174 & 1 & 1585 & 1586 \\
\hline Forestland & 19 & 585 & 603 & 12 & 1458 & 1470 & 0 & 893 & 893 \\
\hline Desert & 1254 & 122 & 1376 & 1439 & 537 & 1977 & 981 & 1096 & 2076 \\
\hline Gobi & 541 & 16,840 & 17,382 & 461 & 17,525 & 17,986 & 214 & 19,901 & 20,116 \\
\hline Grassland & 233 & 745 & 978 & 194 & 563 & 757 & 9 & 425 & 434 \\
\hline Water & 3 & 23 & 26 & 0 & 21 & 21 & 0 & 28 & 28 \\
\hline $\begin{array}{l}\text { Urban/ } \\
\text { developed } \\
\text { land }\end{array}$ & 14 & 285 & 300 & 27 & 545 & 572 & 5 & 986 & 991 \\
\hline Beach land & 9 & 19 & 28 & 30 & 90 & 120 & 12 & 177 & 189 \\
\hline
\end{tabular}

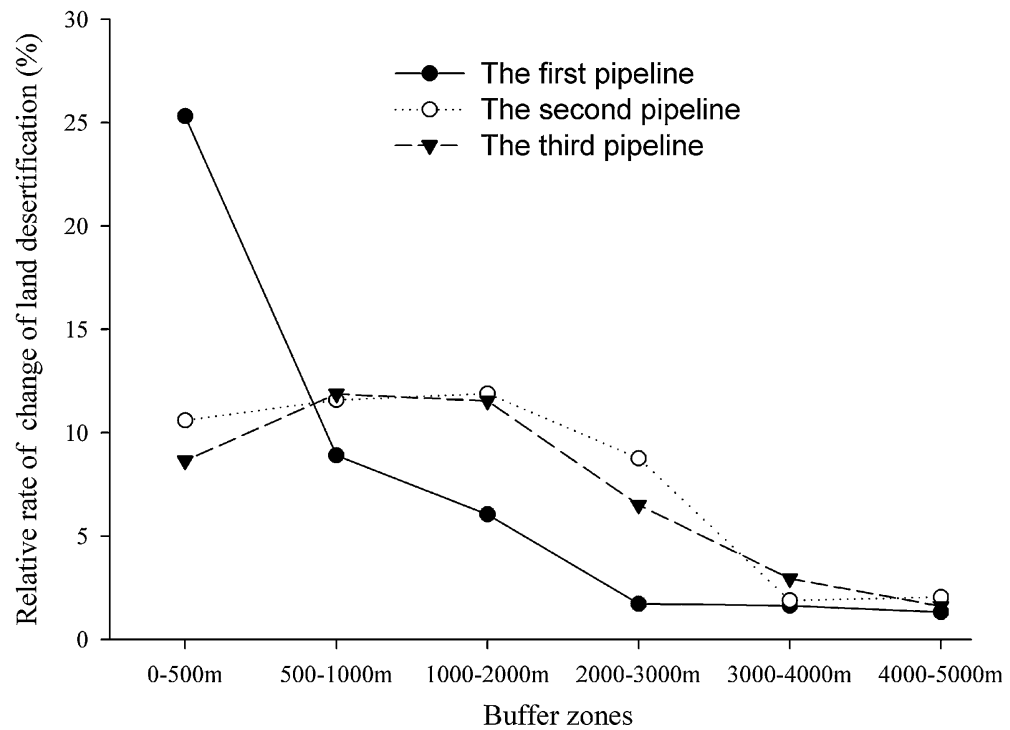

Fig. 4 The relative rate of change of land desertification over different distances of three west-to-east pipelines

The disturbance scale of the first pipeline was mainly within the 2000-m buffer zone. However, the relative rates of increase in land desertification in the 500-1000 and 1000-2000 $\mathrm{m}$ increased about $3 \%$ after the second and third pipeline constructions compared to the first pipeline construction. The increasing levels of disturbance indicated a cumulative temporal impact from the multi-pipelines. The oasis is expected to gradually improve over time, although the disturbance was still evident 2 years after the first pipeline 


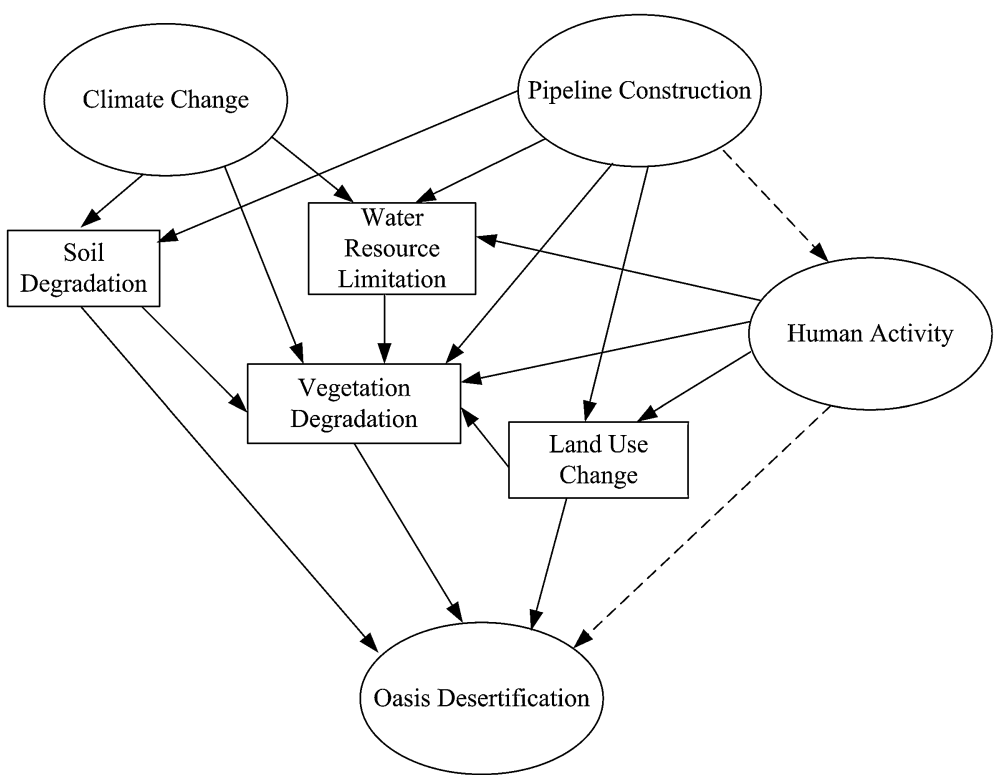

Fig. 5 Driving factors of oasis desertification attributed to natural factors, human activities, and pipeline disturbance

construction. The cumulative temporal impact may have originated from the parallel pipelines.

\section{Discussions}

\subsection{The driving forces of oasis desertification due to pipeline construction}

The oasis desertification changes could be attributed to both fragile ecosystems and human activities (Liu et al. 2010; Qi and Luo 2007). Typical arid land environments (i.e., high evaporation, low precipitation, and frequent wind) are the main natural features in the Heihe River Basin. Precipitation significantly affects vegetation cover (Zhang et al. 2008) and groundwater recharge, leading to the evolution of dune mobilization. Wind activity is a key factor affecting soil erosion and controlling dust transportation, and it plays a major role in the cycles of desertification in arid and semiarid regions of China (Wang et al. 2008). Human activities associated with irrational land development affect oasis stability, causing a series of ecological and environmental issues, including water resource limitation, vegetation degradation, and land desertification (Zhang et al. 2008). To remove the background influence of natural and human factors, the relative rate of land desertification was used in this study to identify the effects of pipeline construction on oasis degradation.

Concerns and studies of the effects of linear projects on ecosystems have increased in recent years (McGarigal et al. 2001; Olson and Doherty 2012; Zhou et al. 2008). Linear projects have been shown to influence soil fertility and decrease species richness and the diversity of plants (Cui et al. 2009). Roads and their construction directly affect plant growth by nitrogen deposition (Lee et al. 2012), heavy metal pollution (Kluge and Wessolek 2012), and soil erosion (Dong et al. 2012). Roads and railways drastically change 
patterns of land use (Cui and Graf 2009; Perz et al. 2013), indirectly alter landscapes, and disturb habitat fragmentation (Hawbaker and Radeloff 2004). In addition, road and railway construction may have indirect effects on water balance and microclimates (Sheridan and Noske 2007). During a railway construction process, the sand crust of the fixed and semifixed dunes alongside the railway was damaged, and the desert area extended (Yuan et al. 2006). Similarly, the extensive impacts of pipeline construction on oases could occur through various ways including direct and indirect disturbances (Fig. 5). During the construction period, a 30-m-wide corridor was cleared for the pipeline route (Fig. 6a). Inevitably, the soil was eroded and covered by wind-blown sand because of the vegetation clearance and topsoil removal. A 2- to 3-m-deep trench was dug in the middle of the pipeline RoW and may have blocked the undercurrent of groundwater, leading to declining groundwater levels (Fig. 6b). The pipeline crossed rivers in arid lands through trenches, which resulted in changes in the river systems and may have had temporal or permanent impacts on the regional water supply (Chen and Gao 2006). The soil in the pipeline corridor suffered salinization due to the sparse vegetation and high evaporation (Fig. 6c). A road located at least $50 \mathrm{~m}$ away from the route was built for pipeline maintenance and monitoring and thus expanded human activities (Fig. 6d). The stability of the oasis was mainly affected by desertification in the oasis-desert ecotone (Su et al. 2007). Overexploitation, including over-reclamation, over-cutting, and over-grazing in the transitional zones, was serious along the pipeline road, and the oasis damage was even more aggravated by the multi-pipeline disturbance, leading to the urgent issue of land desertification.
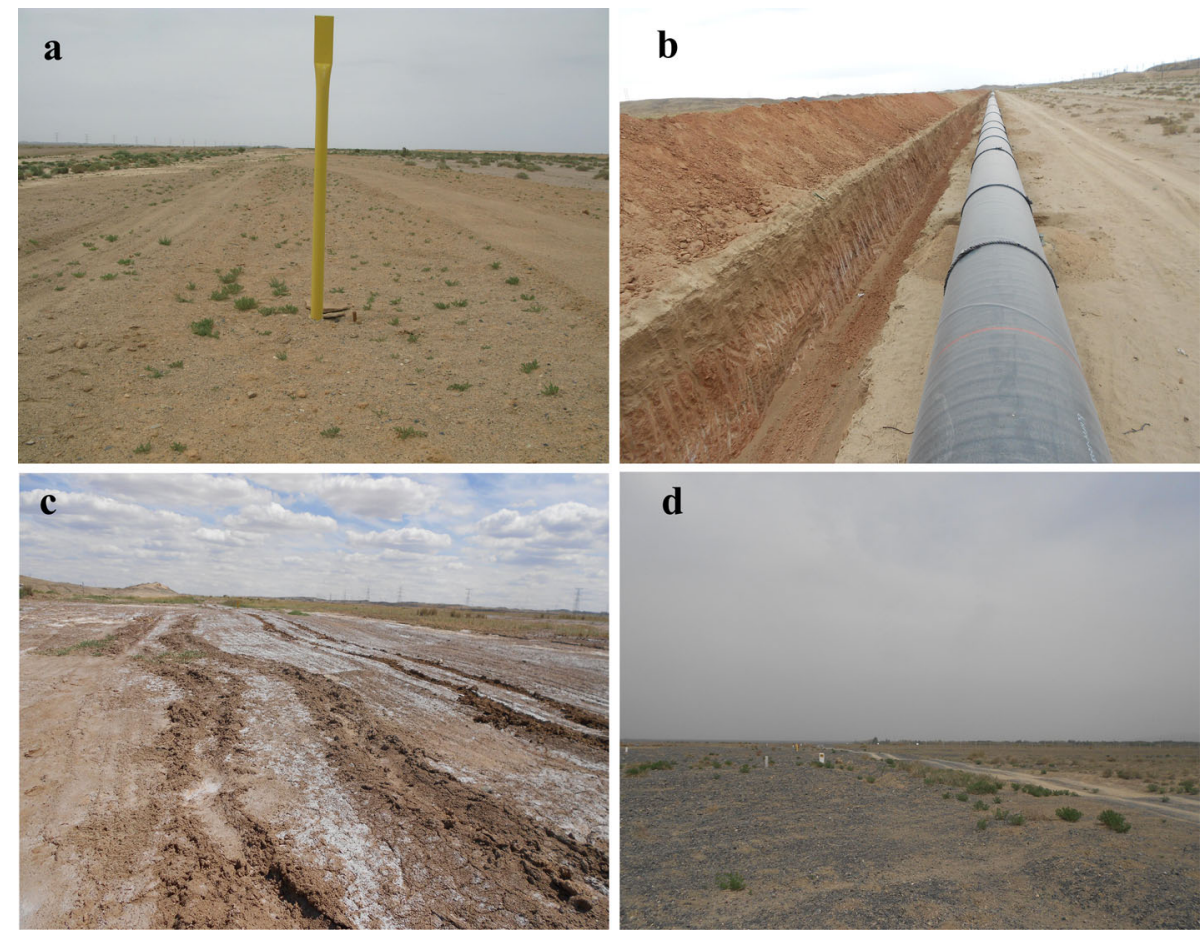

Fig. 6 The extensive impacts of pipeline construction on the oasis. a Topsoil and vegetation clearance in the pipeline right-of-way. b A 2- to 3-m-deep trench dug for pipeline installation. c Soil salinization in areas where natural vegetation was destroyed. d An ancillary road for pipeline maintenance and monitoring 


\subsection{Environmental management of pipeline projects in the oasis region}

The pipeline projects resulted in oasis degradation, and thus, necessary mitigation measures should be implemented. Construction activities must be limited to the $30 \mathrm{~m}$ zone of the pipeline corridor. Topsoil in the pipeline RoW should be removed before installation and backfilled immediately after construction to maintain soil fertility. Vegetation restoration is an effective way to control oasis desertification due to construction projects. Sand-fixing shrubs, such as Haloxylonam modendron, Calligonummongolicum, Tamarix, and Elaeagnus angustifolia, have been shown to contribute to the maintenance of oasis stability (Su et al. 2007). The methods of establishing protective forest belts in the oasisdesert transitional zone and retiring degraded cropland into forest or grassland have been successfully applied to combat desertification (Su et al. 2010). Roads parallel to pipelines should be closed with fences to prevent cutting and grazing along the road. Water supply is limited in the arid oasis, and pipelines should be constructed during the dry season using the method of cofferdam diversion when the project crosses rivers.

\section{Conclusions}

Pipeline construction had significant effects on oasis desertification. The area of desertified land in the study buffer increased by 5885 ha after the construction of three pipelines. The multi-pipelines extended the spatial scale of disturbance. The intensity of land desertification increased within the 2000-m buffer zone after the second and third pipeline disturbances compared to that of the first pipeline. Cropland contributed the most to land desertification. The ancillary road for pipeline maintenance expanded human activities and resulted in over-reclamation along the road. Ecological restoration is necessary for ensuring the security of oases disturbed by pipeline installation. The mitigation measures of soil fertility maintenance, vegetation recovery, road management, and river protection were suggested to take to reduce pipeline impacts on oasis desertification.

Acknowledgments This work was financially supported by the Industry Research Project on Environmental Protection (201209029).

\section{References}

Chen LD, Gao QC (2006) Chance and challenge for China on ecosystem management: lessons from the West-to-East pipeline project construction. Ambio 35:91-93

Coiffait-Gombault C, Buisson E, Dutoit T (2012) Are old Mediterranean grasslands resilient to human disturbances? Acta Oecol 43:86-94

Council on Environmental Quality (1997) Considering cumulative effects under the national environmental policy act. Executive Office of the President, Washington

Cui XF, Graf HF (2009) Recent land cover changes on the Tibetan Plateau: a review. Clim Change 94:47-61

Cui BS, Zhao SQ, Zhang KJ, Li SC, Dong SK, Bai JH (2009) Disturbance of Dabao highway construction on plant species and soil nutrients in Longitudinal Range Gorge Region (LRGR) of Southwestern China. Environ Monit Assess 158:545-559

D’Odorico P, Bhattachan A, Davis KF, Ravi S, Runyan CW (2013) Global desertification: drivers and feedbacks. Adv Water Resour 51:326-344

Dong J, Zhang K, Guo Z (2012) Runoff and soil erosion from highway construction spoil deposits: a rainfall simulation study. Transp Res D Transp Environ 17:8-14 
Hawbaker TJ, Radeloff VC (2004) Roads and landscape pattern in northern Wisconsin based on a comparison of four road data sources. Conserv Biol 18:1233-1244

Kluge B, Wessolek G (2012) Heavy metal pattern and solute concentration in soils along the oldest highway of the world-the AVUS Autobahn. Environ Monit Assess 184:6469-6481

Lee MA, Davies L, Power SA (2012) Effects of roads on adjacent plant community composition and ecosystem function: an example from three calcareous ecosystems. Environ Pollut 163:273-280

Liu SL, Cui BS, Dong SK, Yang ZF, Yang M, Holt K (2008) Evaluating the influence of road networks on landscape and regional ecological risk-a case study in Lancang River Valley of Southwest China. Ecol Eng 34:91-99

Liu W, Cao S, Xi H, Feng Q (2010) Land use history and status of land desertification in the Heihe River basin. Nat Hazards 53:273-290

McGarigal K, Romme WH, Crist M, Roworth E (2001) Cumulative effects of roads and logging on landscape structure in the San Juan Mountains, Colorado (USA). Landsc Ecol 16:327-349

Olson ER, Doherty JM (2012) The legacy of pipeline installation on the soil and vegetation of southeast Wisconsin wetlands. Ecol Eng 39:53-62

Perz SG, Qiu Y, Xia Y, Southworth J, Sun J, Marsik M, Rocha K, Passos V, Rojas D, Alarcon G, Barnes G, Baraloto C (2013) Trans-boundary infrastructure and land cover change: highway paving and community-level deforestation in a tri-national frontier in the Amazon. Land Use Policy 34:27-41

Qi SZ, Luo F (2006) Land-use change and its environmental impact in the Heihe River Basin, arid northwestern China. Environ Geol 50:535-540

Qi SZ, Luo F (2007) Environmental degradation problems in the Heihe River Basin, northwest China. Water Environ J 21:142-148

Sheridan GJ, Noske PJ (2007) Catchment-scale contribution of forest roads to stream exports of sediment, phosphorus and nitrogen. Hydrol Process 21:3107-3122

Shi P, Xiao J, Wang YF, Chen LD (2014) The effects of pipeline construction disturbance on soil properties and restoration cycle. Environ Monit Assess 186:1825-1835

Su YZ, Zhao WZ, Su PX, Zhang ZH, Wang T, Ram R (2007) Ecological effects of desertification control and desertified land reclamation in an oasis-desert ecotone in an arid region: a case study in Hexi Corridor, northwest China. Ecol Eng 29:117-124

Su YZ, Wang XF, Yang R, Lee J (2010) Effects of sandy desertified land rehabilitation on soil carbon sequestration and aggregation in an arid region in China. J Environ Manag 91:2109-2116

Wang XM, Chen F, Hasi E, Li JC (2008) Desertification in China: an assessment. Earth Sci Rev 88:188-206

Wang T, Yan CZ, Song X, Li S (2013) Landsat images reveal trends in the aeolian desertification in a source area for sand and dust storms in China's Alashan Plateau (1975-2007). Land Degrad Dev 24:422-429

Xie YC, Gong J, Sun P, Gou XH (2014) Oasis dynamics change and its influence on landscape pattern on Jinta oasis in arid China from 1963a to 2010a: integration of multi-source satellite images. Int J Appl Earth Obs 33:181-191

Xu DY, Kang XW, Zhuang DF, Pan JJ (2010) Multi-scale quantitative assessment of the relative roles of climate change and human activities in desertification-a case study of the Ordos Plateau, China. J Arid Environ 74:498-507

Yan CZ, Wang T, Han ZW, Qie YF (2007) Surveying sandy deserts and desertified lands in north-western China by remote sensing. Int J Remote Sens 28:3603-3618

Yang X (2001) The oases along the Keriya River in the Taklamakan Desert, China, and their evolution since the end of the last glaciation. Environ Geol 41:314-320

Yang G, Zhou L, Xiao D (2007) Oasis land-use dynamics and its influence on the groundwater in arid Northwest China a case from terminal oasis of Shiyang River Basin. Ambio 36:706-708

Yu XF, Wang GP, Zou YC, Wang QA, Zhao HM, Lu XG (2010) Effects of pipeline construction on wetland ecosystems: Russia-China oil pipeline project (Mohe-Daqing section). Ambio 39:447-450

Yuan SF, Xv JC, Yang LX (2006) The impact of Dunhuang railway construction on land desertification. J Geogr Sci 16:99-104

Zhang YZ, Chen ZY, Zhu BQ, Luo XY, Guan YN, Guo S, Nie YP (2008) Land desertification monitoring and assessment in Yulin of Northwest China using remote sensing and geographic information systems (GIS). Environ Monit Assess 147:327-337

Zhao CY, Nan ZR, Cheng GD (2005) Methods for estimating irrigation needs of spring wheat in the middle Heihe basin, China. Agric Water Manag 75:54-70

Zhao QH, Liu SL, Deng L, Dong SK, Yang ZF, Liu Q (2013) Determining the influencing distance of dam construction and reservoir impoundment on land use: a case study of Manwan Dam, Lancang River. Ecol Eng 53:235-242

Zhou J, Yang J, Peng G (2008) Constructing a green railway on the Tibet Plateau: evaluating the effectiveness of mitigation measures. Transp Res D Transp Environ 13:369-376 